\title{
Growth impairment of primary chondrocyte cells by serum of rats with chronic renal failure
}

\author{
Robert H. Mak ${ }^{1}$, Stella L. Chang ${ }^{1}$ \\ and Youngmi Kim Pak ${ }^{2,3}$ \\ ${ }^{1}$ Division of Pediatric Nephrology \\ Department of Pediatrics \\ Oregon Health and Science University \\ Portland, OR 97201, USA \\ ${ }^{2}$ Asan Institute for Life Sciences \\ University of Ulsan, College of Medicine \\ Seoul 138-736, Korea \\ ${ }^{3}$ Corresponding author: Tel, 82-2-3010-4191; \\ Fax, 82-2-3010-4182; E-mail, ymkimpak@amc.seoul.kr
}

Accepted 17 May 2004

Abbreviations: BUN, blood urea nitrogen; $\mathrm{CRF}$, chronic renal failure; FCS, fetal calf serum; GH, growth hormone; GHBP, GH binding proteins; IGF-I, insulin-like growth factor-l; IGFBP, IGF binding protein; MTT, methylthiazol tetrazolium; SFM, serum free medium

\begin{abstract}
Insulin-like growth factor (IGF)/IGF binding protein (IGFBP) abnormalities may be important in the pathogenesis of growth failure in chronic renal failure (CRF). We induced experimental CRF by $5 / 6$ nephrectomy in Sprague Dawley rats $(100$ g) and observed for 2 weeks comparing with sham-operated pair-fed control rats (Sham-C). CRF rats gained $30 \%$ less height than Sham-C rats $(P<0.01)$. Serum IGFBP profiles by Western ligand blot revealed that IGFBP4 was elevated two fold in CRF rats $(P<0.01$ vs. Sham-C). However, IGFBP4 mRNA levels in liver or skeletal muscle were not different in two groups. To determine if the increase of serum IGFBP4 in CRF retarded the growth of cartilage, epiphyseal chondrocytes were isolated from CRF or control rats and cultured in the presence of control or CRF rat sera. Incubation with $10 \%$ CRF serum reduced proliferations of normal chondrocytes and L6 rat skeletal muscle cells. In contrast, $10 \%$ CRF serum did not inhibit the growth of CRF chondrocytes. Rat sera from two groups were separated into two different fractions, high ( $>10 \mathrm{kDa}$, containing IGFBPs) and low $(<10 \mathrm{kDa}$, containing free IGF) molecular
\end{abstract}

weight fractions using a gel filtration column. Both fractions obtained from CRF sera decreased the growth of control chondrocytes up to $40 \%$ compared with those from control sera. We suggest that the pathogenesis of growth failure in CRF may be involved in the increase of circulating IGFBP4 as well as the unidentified small molecular weight uremic serum factors which block the growth of chondrocytes in growth plate.

Keywords: chondrocytes; CRF; growth failure; IGFBP4; rat; serum factor

\section{Introduction}

Growth retardation is a serious problem found in children with chronic renal failure (CRF). Several factors have been identified as contributors to impaired linear growth and they include protein and calorie malnutrition, metabolic acidosis, growth hormone resistance, anemia, and renal osteodystrophy (Kuizon and Salusky, 1999). For the treatment of these children, supraphysiological concentration of growth hormone $(\mathrm{GH})$ is administered although there is no evidence of $\mathrm{GH}$ deficiency in CRF patients (Mehls et al., 2002). In fact, normal or elevated serum GH concentrations are commonly reported in CRF.

The growth promoting effect of $\mathrm{GH}$ is largely mediated by insulin-like growth factor-I (IGF-I). IGF-I is released from liver after $\mathrm{GH}$ stimulation and the serum IGF-I mediates mitogenic growth of cartilage and bone cells. Therefore, maintenance of the serum GH/IGF-I axis is thought to be important in normal growth, and alteration of this axis is considered as one of the factors for the growth impairment in CRF (Tonshoff et al., 1990). GH bioactivity may be controlled by plasma $\mathrm{GH}$ binding proteins (GHBP) and $\mathrm{GH}$ receptor levels (Tonshoff et al., 1994). Plasma level of GHBP was increased and $\mathrm{GH}$ receptor level in liver was decreased in CRF, which might be causes of $\mathrm{GH}$ resistance. Furthermore serum IGF-I and IGF-II levels were slightly decreased and IGFBP levels were increased in CRF patient sera possibly due to the reduced renal clearance (Mehls et al., 1992). Increase of serum IGFBPs could reduce the bioavailability of free IGF resulting in growth impairment in CRF (Richmond et al., 2001).

Six IGFBPs with high binding affinity to IGFs and 
several IGFBP-rPs with low affinity have been identified from human and rat serum, several body fluids, and cell lines and their cDNAs were all cloned although the roles of individual IGFBP have not been understood clearly (Kim et al., 1997; Hwa et al., 1999). The suggested roles of IGFBPs in circulation are following: 1) IGFBPs inhibit receptor binding of IGF resulting in inhibition of biological activity, 2) BPs may serve as a transporter of IGF to the cell, 3) IGF-IGFBP complexes may interact with the cell surface, 4) free IGFBP itself has biologically active (Oh et al., 1995). The profiles of IGFBPs are different in different biological fluids. In human serum, IGFBP1, IGFBP2 and IGFBP3 are predominantly present while IGFBP1, IGFBP3 and IGFBP4 are in rat serum (Donovan et al., 1989; Oh et al., 1993b). IGFBP4 was first identified as an inhibitory IGFBP on human osteoblast proliferation (LaTour et al., 1990) and further characterized as growth-inhibitory binding proteins in the growth cartilage (Wagner et al., 2000; Kiepe et al., 2001).

In the present study, IGFBPs in rat CRF model were investigated in order to obtain a better understanding the role of IGFBP on growth defect in CRF patient. The effects of the CRF and control sera on the growth of rat epiphyseal chondrocytes were studied. The results could provide us a direct evidence for the inhibitory effects of serum components on the growth of growth plate chondrocytes.

\section{Materials and Methods}

\section{Animals}

Male Sprague-Dawley rats $(100 \mathrm{~g})$ underwent 5/6 nephrectomy or sham operation. Sham-operated animals were pair-fed to nephrectomized rats and water was provided. Two weeks after the operation, serum, liver, skeletal muscle, and joints were obtained during nembutol anesthesia. Before and after the experiment the weight and nose to tail length of the rat were measured. Serum and urine creatinine, and blood urea nitrogen (BUN) level was determined as described previously (Mak and Pak, 1996).

\section{Western ligand blot}

Rat serum $(2 \mu \mathrm{l})$ were separated on $12 \%$ SDS-PAGE and western ligand blot using ${ }^{125}$ I-IGF-I and ${ }^{125}$ I-IGF-II was performed as described (Hossenlopp et al., 1986). Urine samples were concentrated (1:10) using Centricon-10 (Amicon Inc, MA) and $100 \mu$ l of concentrated urine was analyzed as described above. The nitrocellulose paper was autoradiographed and the bands were quantified by densitometry.

\section{Imm unoprecipitation}

Serum samples $(2 \mu \mathrm{l})$ were immunoprecipitated with anti-rat IGFBP4 antibody (kindly provided by Dr. R. Rosenfeld, Univ. of Oregon Health Science, OR) and separated on $12 \%$ SDS-PAGE. The gel was transferred onto nitrocellulose membrane, and then western ligand blot was performed as described above.

\section{Northern blot analysis}

Total RNA was isolated from different tissues as described by Chomzynski and Sacchi (Chomczynski and Sacchi, 1987; Eum et al., 2003). RNA was separated on $1 \%$ agarose $/ 2.4 \mathrm{M}$ formaldehyde gels, transferred to Nitroplus 2,000 paper (Microseparation Inc., Wesrboough, MA), and subsequently hybridized with ${ }^{32} \mathrm{P}$-labeled human IGFBP4 cDNA probe $(1.2 \mathrm{~kb}$ Xhol fragment, a generous gift from Dr. R. G. Rosenfeld, Oregon Health Science Center) as described previously (Fong et al., 1995). For normalization of even loading, glyceraldehyde 3-phosphate dehydrogenase (G3PDH) mRNA was also determined using cDNA probe (Pak et al., 1996).

\section{Serum fractionation}

Pool of sera obtained from either control or CRF rats were fractionated into two different molecular weight parts using G200-Sephadex chromatography (Martin and Baxter, 1986). Collected fractions were lyophilized and reconstituted in water to the original volume. High and low molecular weight fractions were named as BP $(>10 \mathrm{kDa})$ and IGF $(<10 \mathrm{kDa})$ fractions, respectively.

\section{Cell culture and primary epiphyseal chondrocyte culture}

Rat epiphyseal chondrocytes were isolated as described previously. Briefly, cartilage from rat tibial growth plate was dissected, digested with collagenase (Type II and IV, Worthington Biochemicals, Freewood, $\mathrm{NJ}$ ), washed with phosphate buffered saline and filtered though a $100 \mathrm{~mm}$ polypropylene mesh (Mak and Pak, 1996). Cell number was determined by counting on a hemocytometer and viability was determined by tryphan blue dye exclusion. In each isolation, cells from 4 rats per group were pooled. Subsequently, cells were suspended in complete media: 1:1 mixture of Dulbecco's minimum essential medium (DMEM) and Ham's F12 supplemented with gentamicin and 10\% fetal calf serum (FCS) and grown until confluence on $100 \mathrm{~mm}$ culture dishes. The cells were then trypsinized and seeded in 24 well plates coated with poly-L-lysine at a density of $4 \times 10^{4}$ cells per well and allowed to attach to the plate in $10 \%$ FCS for 24 
Table 1. Growth and blood chemistry of the CRF and sham-control rats.

\begin{tabular}{lllllll}
\hline Group & $\begin{array}{c}\text { Initial } \\
\text { weight }(\mathrm{g})\end{array}$ & $\begin{array}{c}\text { Weight } \\
\text { gain }(\mathrm{g})\end{array}$ & $\begin{array}{c}\text { Initial } \\
\text { length }(\mathrm{cm})\end{array}$ & $\begin{array}{c}\text { Length } \\
\text { gain }(\mathrm{cm})\end{array}$ & $\begin{array}{c}\text { BUN }{ }^{\mathrm{a}} \\
(\mathrm{mg} / \mathrm{dl})\end{array}$ & $\begin{array}{c}\text { Serum } \\
\text { creatinine }(\mathrm{mg} / \mathrm{dl})\end{array}$ \\
\hline CRF $(n=12)$ & $99.1 \pm 2.1$ & $32.2^{*} \pm 7.1$ & $27.4 \pm 0.5$ & $4.3^{*} \pm 0.40$ & $35.8^{*} \pm 4.4$ & $0.72^{*} \pm 0.09$ \\
Sham-C $(n=11)$ & $99.7 \pm 2.2$ & $57.5 \pm 4.3$ & $27.0 \pm 0.3$ & $6.3 \pm 0.7$ & $12.5 \pm 1.3$ & $0.41 \pm 0.05$
\end{tabular}

${ }^{a} B U N$, blood urea nitrogen. Data $=$ Mean \pm SD. *: $P<0.01$ vs Sham $-C$.

A

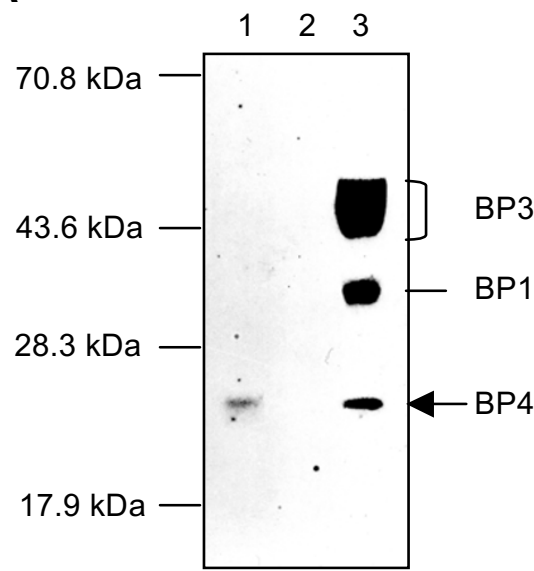

B

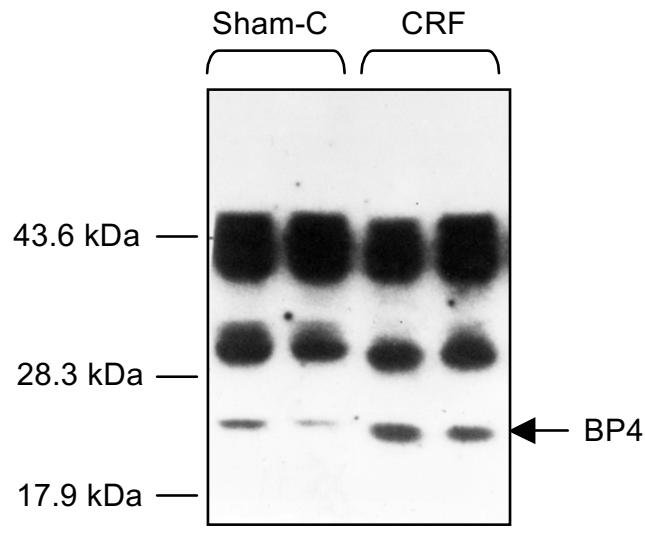

Figure 1. Western ligand blots of rat sera (A) Rat serum $(2 \mu \mathrm{l})$ was either immunoprecipitated using anti-rat IGFBP4 antibody (lane 1) or control antibody (lane 2) separated on 12\% SDS-PAGE Serum sample without immunoprecipitation is shown in lane 3 (B) Sera $(2 \mu \mathrm{l})$ obtained from sham-operated control (Sham-C) and CRF (CRF) rats were separated on 12\% SDS-PAGE. The gels were transferred onto nitrocellulose membrane, and incubated with ${ }^{125}$ I-IGF-I and ${ }^{125}$ I-IGF-II. The membrane was washed and autoradiographed. The position of IGFBP4 was marked with arrows.

$h$. Then the cells were washed and resuspended in serum free medium (SFM): 1:1 mixture of DMEM and Ham's F12 supplemented with gentamicin, $20 \mathrm{nM}$ selenium and lipid emulsion containing lecithin, cholesterol, sphingomyelin, vitamin $E$ and vitamin $E$ acetate. L6 rat skeletal muscle cells were grown in DMEM supplemented with $10 \% \quad(\mathrm{v} / \mathrm{v})$ fetal bovine serum in a humidified atmosphere of $95 \%$ air and $5 \%$ $\mathrm{CO}_{2}$ at $37^{\circ} \mathrm{C}$. For growth assessment, the cells were incubated with SFM for $48 \mathrm{~h}$, and the test sera obtained from CRF and control rats were added into each well and incubated for $24 \mathrm{~h}$. Cell number, ${ }^{3} \mathrm{H}$-thymidine incorporation or mitogenic activity using methylthiazol tetrazolium (MTT) were determined as described (Mak and Pak, 1996).

\section{Statistics}

All growth studies were repeated 4-6 times using different pools of cells. Each pool of cells was obtained from 3-4 different rats of CRF and control, respectively. Unpaired t-test using unequal variance was used for statistical analysis. $P$ values less than 0.05 was accepted as statistically significant.

\section{Results}

Renal failure of nephrectomized animals was confirmed by BUN (CRF, $35.8 \pm 4.4 \mathrm{mgl} / \mathrm{dl}$; Sham-C, $12.5 \pm 1.3 \mathrm{mgl} / \mathrm{dl}$ ) and serum creatinine (CRF, 0.72 $\pm 0.09 \mathrm{mgl} / \mathrm{dl}$; Sham $-\mathrm{C}, 0.41 \pm 0.05 \mathrm{mgl} / \mathrm{dl}$ ) that were much higher $(P<0.01)$ than those of sham animals (Table 1). Weight and longitudinal growth of CRF and control rats are presented in Table 1 . CRF rats grew $30 \%$ less than the controls $(P<0.01)$.

To determine the levels of IGFBPs in rat serum, Western ligand blots were carried out. As shown in Figure 1, IGFBP3 complexes (45 kDa), IGFBP1 (32 $\mathrm{kDa})$ and IGFBP4 (24 kDa) were observed predominantly in rat serum. This profile is different from that of human in which IGFBP1 and IGFBP3 are major IGFBPs (LaTour et al., 1990). The band of $24 \mathrm{kDa}$ protein was confirmed as IGFBP4 by immunoprecipitation using antibody raised against rat IGFBP4 
A Liver

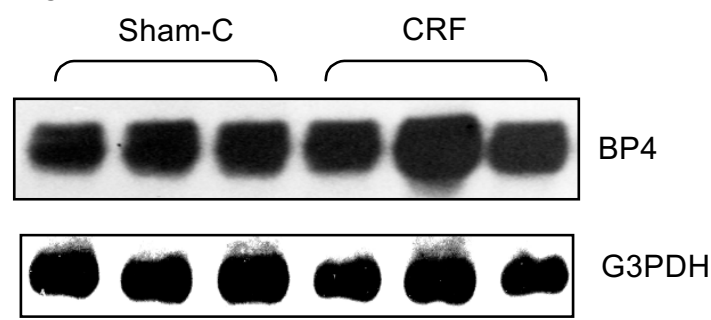

\section{B Skeletal muscle}
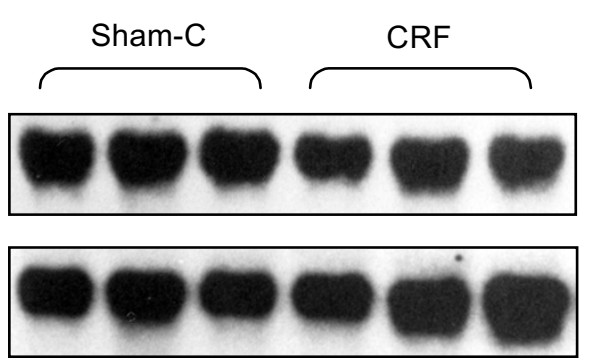

BP4

G3PDH

Figure 2. Northern blot analysis of IGFBP4. Total RNA was isolated from liver or skeletal muscle obtained from sham control (Sham-C) and CRF rats (CRF). Northern blot analysis was performed as described in Method section. The mRNA levels of IGFBP4 and G3PDH were quantified using densitometer and relative levels of IGFBP4 expression were determined to the level of G3PDH. (lane1, Figure 1A). Figrue 1B showed that the levels of IGFBP4 were approximately 2 fold increased in CRF compared with those of controls $(P<0.01)$. The levels of other IGFBPs were not different in two groups.

To determine if the increase of serum IGFBP4 was resulted from its enhanced synthesis, the steady state levels of IGFBP4 mRNA in liver and skeletal muscle, which were major sources of IGFBP production, were determined by Northern blots. Figure 2 showed that IGFBP4 mRNA levels were not altered in CRF tissues. The result tells us that the IGFBP4 increase in CRF is not a result from the increased steady state mRNA levels in liver and skeletal muscle.

In order to determine whether the CRF serum has direct effects on the growth of cartilage, epiphyseal chondrocytes were isolated and the effects of CRF rat serum on proliferation of the chondrocyte cells in primary culture were studied. The serum obtained from CRF rats inhibited the incorporation of ${ }^{3} \mathrm{H}$ - thymidine $(P<0.01$, Figure $3 \mathrm{~A})$ and the proliferation of control chondrocytes in cell number to the null $(P<0.01$, Figure 3B) when $10 \%$ concentration was utilized. At $10 \%$ concentration, the CRF serum also blocked the growth of L6 rat skeletal muscle cells in aspects of cell number and thymidine incorporation (Figure 4). Interestingly, the CRF serum did not affect
A

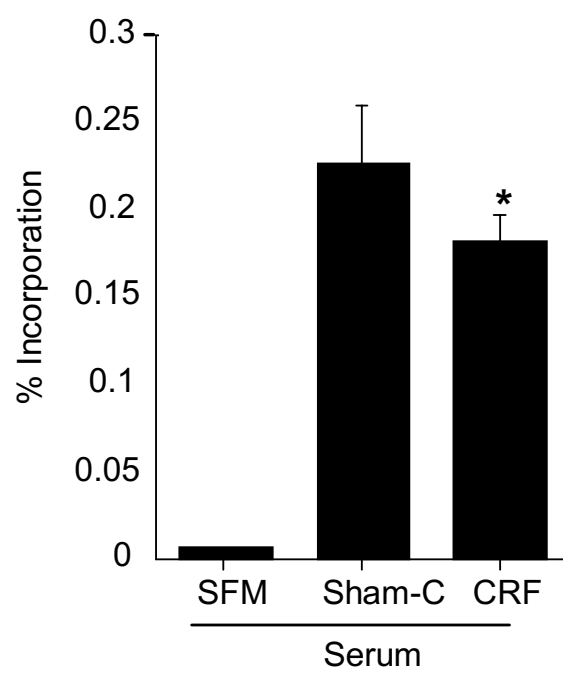

B

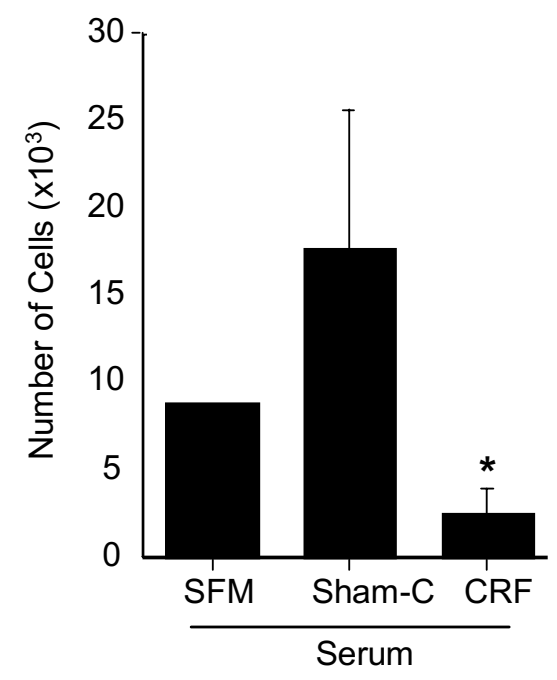

Figure 3. Effects of rat sera on the proliferation of normal chondrocytes. Epiphyseal chondrocytes were isolated from sham-control rats. The cells were cultured in SFM on 24-well plate in the presence of either $10 \%$ control (Sham-C) or CRF rat sera for $24 \mathrm{~h}$. Cell proliferation was assessed by ${ }^{3} \mathrm{H}$-thymidine incorporation (panel A) and counting cells using hemocytometer (panel B). For ${ }^{3} \mathrm{H}$-thymidine incorporation, radiolabeled thymidine was added $18 \mathrm{~h}$ prior to harvesting cells. \% incorporation was calculated by radioactivity associated with cells divided with total radioactivity. *: $P<0.01$ vs Sham-C. 
A

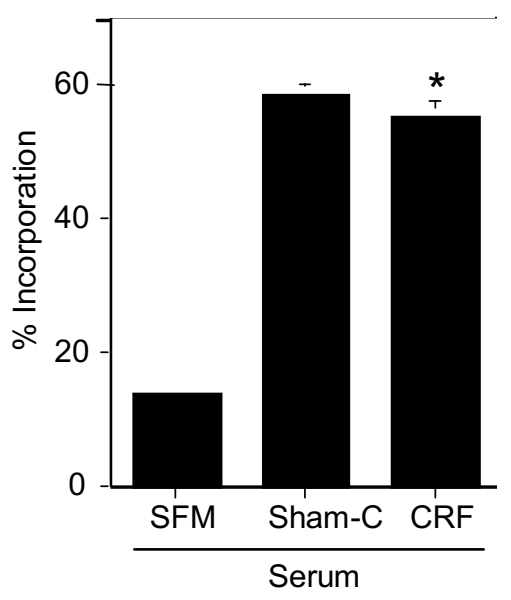

B

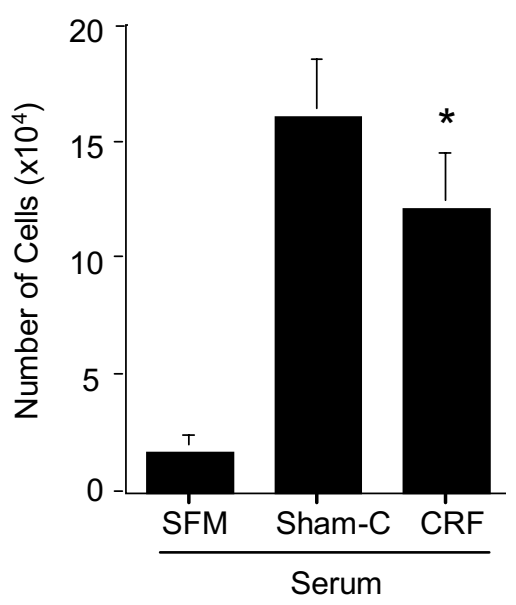

Figure 4. Effects of rat sera on the proliferation of $L 6$ rat skeletal muscle cells. $L 6$ cells were grown on 24 -well plate and the effects of $10 \%$ control (Sham-C) or CRF rat sera in serum free media (SFM) were measured as described in Figure 3. ${ }^{*}: P<0.01$ vs Sham-C

A

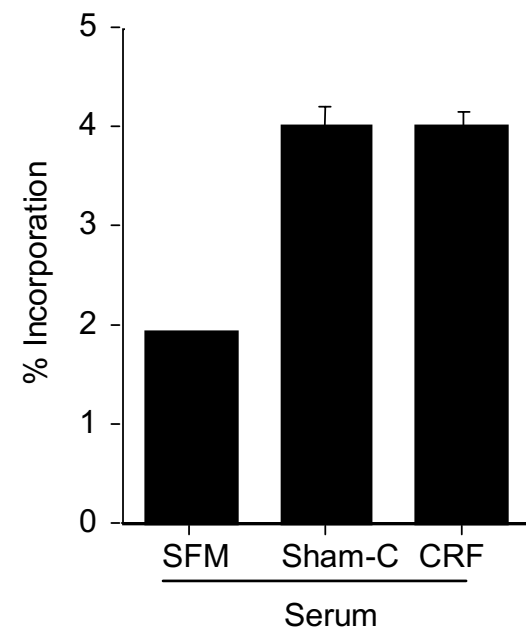

B

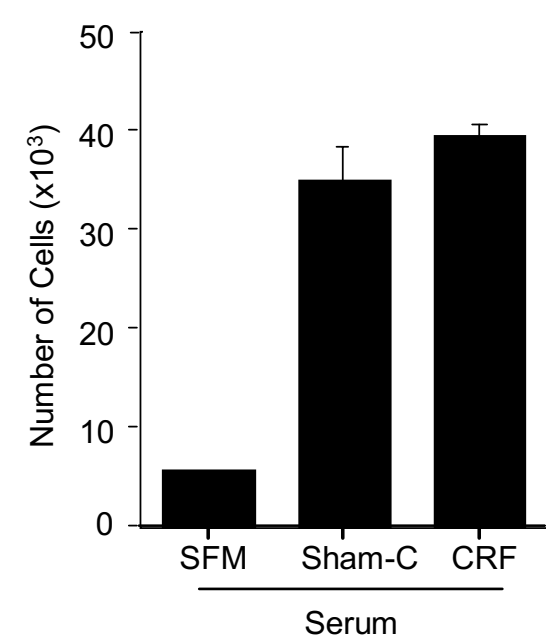

Figure 5. Effects of rat CRF serum on the proliferation of CRF chondrocytes Epiphyseal chondrocytes were isolated from CRF rats and the effects of $10 \%$ control (Sham-C) or CRF rat sera in serum free media (SFM) were examined as described in Figure 3.

the growth of CRF chondrocytes (Figure 5). MTT mitogenic assay showed that the CRF serum inhibited the growth of the control chondrocytes at $10 \%$, probably above $5 \%$ concentration (Figure 6).

IGFBP4 was reported as an inhibitory protein on cell proliferation. Since we observed the IGFBP4 protein levels in CRF serum increased, IGFBP4 was thought to be a candidate component which might be responsible for growth failure in CRF. Therefore, the sera obtained from either CRF or control rats were partially purified into two different molecular weight fractions containing either IGFBP proteins or free IGFs using gel filtration chromatography. The obtained two fractions were named as BP $(>10 \mathrm{kDa})$ and IGF $(<$ $10 \mathrm{kDa}$ ) fractions, respectively. Chondrocytes were then incubated with $10 \%$ of the BP or IGF fractions reconstituted after lyophilization. Unexpectedly, both fractions from CRF sera retarded the growth of the control cells to the similar extent $(40 \%, P<0.05)$ when the growth responses were compared to the 


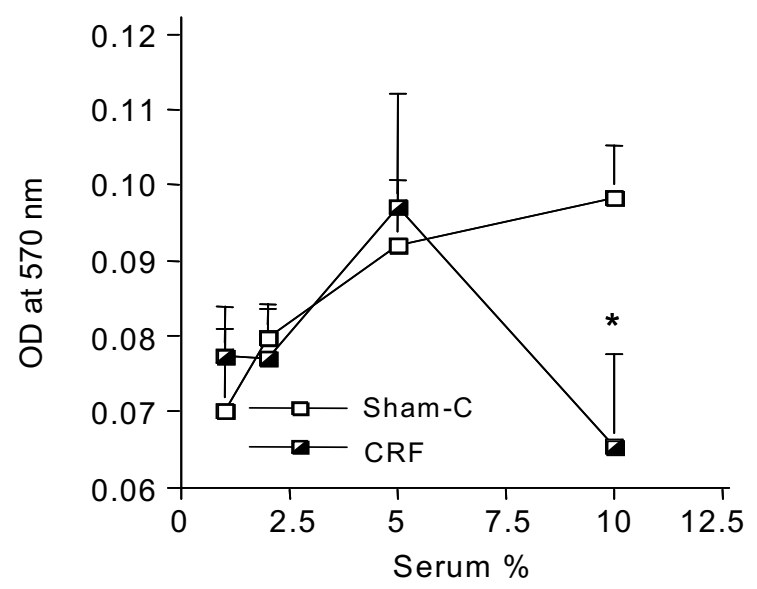

Figure 6. Dose-response of control (Sham-C) or CRF rat sera on the proliferation of normal chondrocytes determined by MTT assay. Epiphyseal chondrocytes were isolated from sham-control rats and the effects of different concentrations of control and CRF rat sera in serum free media (SFM) were examined by mitogenic MTT assay. ${ }^{*}: P<$ 0.01 vs Sham-C at $10 \%$

fractions separated from the control rats (Figure 7). But both CRF serum fractions did not retard the proliferation of CRF cells (data not shown).

\section{Discussion}

Increase of IGFBPs in CRF patient serum has been noticed for a long time but the exact role of IGFBPs in CRF has not been clearly understood. This study demonstrated that the possible growth impairment effect of IGFBPs in CRF serum on primary culture of epiphyseal chondrocytes. Since human and rat IGFBP profiles were different, different IGFBP would be altered in rat models. As expected, IGFBP4 was increased in CRF rat serum rather than IGFBP3 which was increased in human CRF serum (Tonshoff et al., 1994). IGFBP3 concentration in human CRF serum was increased due to the decreased serum and urine protease activity towards IGFBP3 (Lee et al., 1994) but the mechanism of IGFBP4 increase in rat CRF serum have not been studied. As shown in Figure 2, IGFBP4 mRNA expression in liver and skeletal muscle was not changed in CRF rats compared to the controls. We observed that neither protease activity in rat CRF serum nor IGFBP4 clearance in urine was altered when they were determined by radiolabeled IGFBP4 degradation and urine western ligand blots (data not shown). Therefore, IGFBP4 in rat CRF serum seemed to be enhanced by unidentified mechanism. One of the possible steps might be the release of IGFBP4 from the local storage, such as IGFBP receptor, which was identified in IGFBP3 system (Oh et al., 1993c).

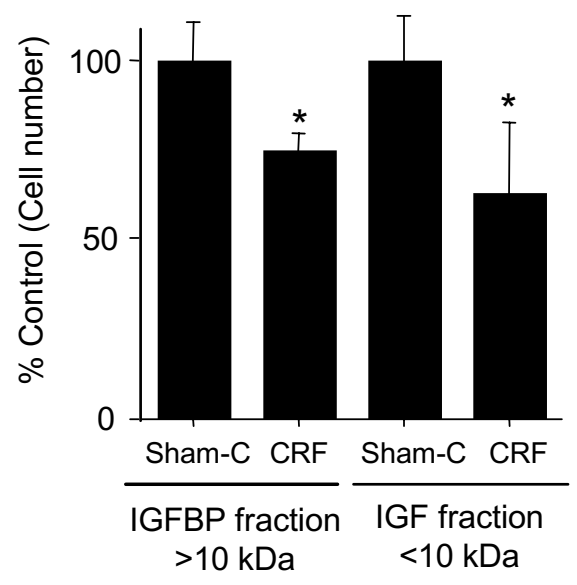

Figure 7. Effect of serum IGFBP and IGF fractions on the growth of normal chondrocytes. Epiphyseal chondrocytes were isolated from control rats and the effects of the IGFBP $(>10 \mathrm{kDa})$ and IGF $(<10 \mathrm{kDa})$ fractions obtained from sham-control (Sham-C) or CRF rat sera in serum free media (SFM) were examined as described in Figure 3.

However, the presence of receptor for IGFBP4 has yet been reported.

It has been demonstrated that IGFBPs may be an important regulator of the cell growth. IGFBPs might inhibit the growth response of IGF through binding to IGF and reducing the bioavailabilty of IGF. Overexpression of IGFBP3 inhibited the growth of breast cancer cells (Oh et al., 1993a; Oh et al., 1995) and IGFBP4 inhibited human osteoblast and osteosarcoma cell proliferation (Mohan et al., 1989). Since growth retardation in CRF patients and rat CRF models would be a result of serum IGFBP4 increase that might decrease or prevent IGF binding to its signaling receptor or IGFBPs might exert a direct effect on the growth of cartilage. Our results demonstrated that rat CRF serum inhibited the proliferation of normal chondrocyte primary cultures when it was present at $10 \%$ concentration and the CRF serum concentration lower than $10 \%$ did not inhibit the proliferation of the normal cells. Thus it was suggested that certain levels of inhibitory molecules in CRF serum were necessary for the effects. The same concentration $(10 \%)$ of CRF serum did not inhibit the proliferation of the CRF chondrocytes. This is an interesting observation suggesting that CRF chondrocytes are different from normal chondrocytes in responding to exogenous stimuli. This may be because cells undergo an "adaptation" process to survive when the cells are exposed to CRF serum environment for a long time. The end-organ resistance of CRF chondrocytes to the growth stimulating peptides which we reported previously (Mak and Pak, 1996) would be one of adaptation processes.

To identify the nature of the inhibiting molecules, 
probably IGFBP4, the CRF and control rat sera were fractionated into high and low molecular weight parts. High molecular weight fractions $(>10 \mathrm{kDa})$ contained IGFBPs and IGF-IGFBP complexes, and the low molecular weight fractions $(<10 \mathrm{kDa})$ did free IGF. This fractionation method was usually used for determining the concentration of free IGF in serum. Interestingly both fractions retarded proliferation of normal chondrocytes, but not of CRF cells. Cell proliferation inhibitory effects of the fractionated CRF serum were less than those of whole CRF serum. It is possible that inhibitory molecules in BP fractions might be either free IGFBP4 or IGF-IGFBP4 complexes. Inhibitory molecules in IGF fractions might be the unidentified novel small molecules present in CRF serum. Inhibition of chondrocyte proliferation of whole CRF serum would be additive or synergistic effects of those two high and low molecular weight molecules. Further studies are required to characterize the nature of the molecules in detail.

\section{References}

Chomczynski $P$, Sacchi N. Single-step method of RNA isolation by acid guanidinium thiocyanate-phenol-chloroform extraction. Anal Biochem 1987;162:156-9

Donovan SM, Oh Y, Pham H, Rosenfeld RG. Ontogeny of serum insulin-like growth factor binding proteins in the rat. Endocrinology 1989;125:2621-7

Eum WS, Li MZ, Sim GS, Choi SY, Park JB, Lee JY, Kwon HY. Dexamethasone-induced differentiation of pancreatic AR42J cell involves $p 21^{\text {wafi/CIP1 }}$ and MAP kinase pathway. Exp Mol Med 2003;35:379-84

Fong LG, Fujishima SE, Komaromy MC, Pak YK, Ellsworth $J L$, Cooper AD. Location and regulation of low-density lipoprotein receptors in intestinal epithelium. Am $\mathrm{J}$ Physio 1995;269:G60-72

Hossenlopp P, Seurin D, Segovia-Quinson B, Hardouin S, Binoux M. Analysis of serum insulin-like growth factor binding proteins using western blotting: use of the method for titration of the binding proteins and competitive binding studies. Anal Biochem 1986;154:138-43

Hwa V, Oh Y, Rosenfeld RG. The insulin-like growth factorbinding protein (IGFBP) superfamily. Endocr Rev 1999;20: 761-87

Kiepe D, Andress DL, Mohan S, Standker L, Ulinski T, Himmele R, Mehls O, Tonshoff B. Intact IGF-binding protein-4 and -5 and their respective fragments isolated from chronic renal failure serum differentially modulate IGF-I actions in cultured growth plate chondrocytes. J Am Soc Nephrol 2001;12:2400-10

Kim HS, Nagalla SR, Oh Y, Wilson E, Roberts CT Jr, Rosenfeld RG. Identification of a family of low-affinity insulinlike growth factor binding proteins (IGFBPs): characterization of connective tissue growth factor as a member of the IGFBP superfamily. Proc Natl Acad Sci USA 1997;94:12981-6
Kuizon BD, Salusky IB. Growth retardation in children with chronic renal failure. J Bone Miner Res 1999;14:1680-90

LaTour D, Mohan S, Linkhart TA, Baylink DJ, Strong DD. Inhibitory insulin-like growth factor-binding protein: cloning, complete sequence, and physiological regulation. Mol Endocrinol 1990;4:1806-14

Lee DY, Park SK, Yorgin PD, Cohen P, Oh Y, Rosenfeld RG. Alteration in insulin-like growth factor-binding proteins (IGFBPs) and IGFBP-3 protease activity in serum and urine from acute and chronic renal failure. J Clin Endocrinol Metab 1994;79:1376-82

Mak RH, Pak YK. End-organ resistance to growth hormone and IGF-I in epiphyseal chondrocytes of rats with chronic renal failure. Kidney Int 1996;50:400-6

Martin JL, Baxter RC. Insulin-like growth factor-binding protein from human plasma Purification and characterization $\mathrm{J}$ Biol Chem 1986;261:8754-60

Mehls O, Blum WF, Schaefer F, Tonshoff B, Scharer K. Growth failure in renal disease. Baillieres Clin Endocrinol. Metab 1992;6:665-85

Mehls O, Schaefer F, Tonshoff B, Wuhl E. Effectiveness of growth hormone treatment in short children with chronic renal failure. J Pediatr 2002;141:147-8

Mohan S, Bautista CM, Wergedal J, Baylink DJ. Isolation of an inhibitory insulin-like growth factor (IGF) binding protein from bone cell-conditioned medium: a potential local regulator of IGF action. Proc Natl Acad Sci USA 1989;86:8338-42

Oh $Y$, Muller $\mathrm{HL}$, Lamson $\mathrm{G}$, Rosenfeld RG. Insulin-like growth factor (IGF)-independent action of IGF-binding protein-3 in Hs578T human breast cancer cells. Cell surface binding and growth inhibition. J Biol Chem 1993a;268: 14964-71

Oh Y, Muller HL, Lee DY, Fielder PJ, Rosenfeld RG. Characterization of the affinities of insulin-like growth factor (IGF)-binding proteins 1-4 for IGF-I, IGF-II, IGF-I/insulin hybrid, and IGF-I analogs. Endocrinology 1993b;132:1337- 44

Oh Y, Muller HL, Pham H, Rosenfeld RG. Demonstration of receptors for insulin-like growth factor binding protein-3 on Hs578T human breast cancer cells. J Biol Chem 1993c;268: 26045-8

Oh Y, Gucev Z, Ng L, Muller HL, Rosenfeld RG. Antiproliferative actions of insulin-like growth factor binding protein (IGFBP)-3 in human breast cancer cells. Prog Growth Factor Res 1995;6:503-12

Pak YK, Kanuck MP, Berrios D, Briggs MR, Cooper AD, Ellsworth JL. Activation of LDL receptor gene expression in HepG2 cells by hepatocyte growth factor. J Lipid Res 1996;37:985-98

Richmond EJ, Uzri A, Rogol AD. The insulin-like growth factor system in kidney diseases. Nephron 2001;89:5-9

Tonshoff B, Schaefer F, Mehls O. Disturbance of growth hormone--insulin-like growth factor axis in uraemia Implications for recombinant human growth hormone treatment Pediatr Nephrol 1990;4:654-62 
Tonshoff B, Eden S, Weiser E, Carlsson B, Robinson IC, Blum WF, Mehls $O$. Reduced hepatic growth hormone $(\mathrm{GH})$ receptor gene expression and increased plasma $\mathrm{GH}$ binding protein in experimental uremia Kidney. Kidney Int 1994;45: 1085-92
Wagner MS, Stracke S, Jehle PM, Keller F, Zellner D, Baylink DJ, Mohan S. Evaluation of IGF system component levels and mitogenic activity of uremic serum on normal human osteoblasts. Nephron 2000;84:158-66 